\title{
KESESUAIAN TATA LAKSANA PSORIASIS DENGAN PANDUAN PRAKTIK KLINIS (PPK) DI RSUPN DR. CIPTO MANGUNKUSUMO
}

\author{
Windy Keumala Budianti, Shafira Anindya, Arlha Aporia Debinta, Endi Novianto, \\ Eyleny Meisyah Fitri, Evita Halim Effendi
}

Departemen Ilmu Kesehatan Kulit dan Kelamin FK Universitas Indonesia/RSUPN dr. Cipto Mangunkusumo

\begin{abstract}
ABSTRAK
Psoriasis merupakan peradangan kulit kronik dengan dasar genetik. Untuk mencapai remisi dan kualitas hidup yang baik, pilihan terapi disesuaikan dengan kebutuhan perorangan pasien. Tipe dan derajat keparahan psoriasis perlu ditentukan guna memilih tata laksana yang sesuai karena memengaruhi keberhasilan terapi, masa remisi, serta tingkat morbiditas. Penelitian ini bertujuan menilai kesesuaian tata laksana psoriasis berdasarkan derajat keparahan dengan menggunakan Panduan Praktik Klinis (PPK) RSUPN dr. Cipto Mangunkusumo (RSCM) dan Persatuan Dokter Spesialis Kulit dan Kelamin Indonesia (PERDOSKI). Studi retrospektif ini mengambil subjek seluruh pasien baru psoriasis di Divisi Alergi Imunologi, Departemen Ilmu Kesehatan Kulit dan Kelamin RSCM periode Oktober 2017 - Oktober 2018. Keparahan psoriasis dinilai dengan skor body surface area (BSA) dan psoriasis area severity index (PASI). Sebanyak 32 di antara 35 pasien (91,4\%), skor BSA dan/atau PASI terdokumentasi pada rekam medis, dan 30 di antara 32 pasien $(93,8 \%)$, mendapatkan pilihan terapi sesuai dengan tipe psoriasis atau skor BSA dan/atau PASI. Kepatuhan pasien sangat penting sehingga pemilihan tata laksana psoriasis perlu mempertimbangkan kenyamanan pasien terkait efek samping pengobatan, kemudahan pasien untuk mengakses fasilitas, dan aspek ekonomi. Kesesuaian terapi tidak mencapai 100\% karena kontraindikasi pemberian terapi standar, penolakan pasien, dan ketidaktersediaan obat misalnya metotreksat. Sebanyak 93,8\% pasien psoriasis di RSCM telah ditata laksana sesuai dengan PPK RSCM dan PERDOSKI.
\end{abstract}

Kata Kunci: BSA, PASI, psoriasis, tata laksana

\section{THE CONFORMITY OF PSORIASIS MANAGEMENT ACCORDING TO PRACTICAL CLINICAL GUIDELINES IN DR. CIPTO MANGUNKUSUMO NATIONAL CENTRAL GENERAL HOSPITAL}

\section{Korespondensi:}

J1. Diponegoro 71,

Jakarta Pusat

Tel: 021-31935383

Email: shafiraanindya@gmail.com

\begin{abstract}
Psoriasis is a chronic inflammatory skin disease with genetic susceptibility. To achieve complete remission and good quality of life, treatments may be tailored individually based on types and severity of psoriasis. This study aims to assess the conformity of psoriasis treatment according to practical clinical guidelines applied in dr. Cipto Mangunkusumo National Central General Hospital (RSCM) and Indonesian Society of Dermatology and Venereology (INSDV). This retrospective study was held by collecting data from medical records of all new psoriasis patients coming to Allergy-Immunology Division, Dermatovenereology Department, RSCM from October 2017 to September 2018. Treatments were chosen based on the severity, measured by body surface area (BSA) and psoriasis area severity index (PASI) scores. BSA and/or PASI scores were determined in 32 out of 35 patients (91.4\%). Thirty out of 32 patients (93.8\%) got the appropriate therapy. Patient's compliance is crucial. Thus, treatment selection should consider the economical aspect, availability, and side effects of treatment. The conformity of treatment was not $100 \%$ achieved because of contraindication to standard therapy, refusal of the patient, and unavailability of treatment modalities. About $93.8 \%$ psoriasis cases in RSCM have been treated according to guidelines provided by RSCM and INSDV
\end{abstract}

Keywords: BSA, PASI, psoriasis, treatment 


\section{PENDAHULUAN}

Psoriasis merupakan peradangan kulit kronis dengan dasar genetik yang kuat. ${ }^{1,2}$ Pada kulit pasien psoriasis terjadi perubahan pertumbuhan dan diferensiasi sel epidermis. ${ }^{1,2}$ Istilah psoriasis berasal dari bahasa Yunani 'psora' yang berarti gatal. ${ }^{3}$ Psoriasis sebelumnya dikenal sebagai kelainan primer pada keratinosit, namun saat ini diketahui bahwa psoriasis merupakan penyakit sistemik berdasarkan patogenesis autoimunologik dan genetik yang bermanifestasi di kulit, sendi, serta terkait sindrom metabolik..$^{1-3}$

Penyebab psoriasis hingga saat ini belum diketahui dengan pasti, namun pemeriksaan genom manusia menunjukkan sembilan lokus berbeda dengan kerentanan terhadap psoriasis (PSORS 1-9), yang merupakan bagian major histocompatibility complex (MHC) di kromosom 6p2. Genom ini merupakan penentu utama pada 50\% psoriasis dengan kerentanan genetik. ${ }^{4}$ Mekanisme peradangan kulit pada psoriasis cukup kompleks dan melibatkan berbagai sitokin, kemokin, dan faktor pertumbuhan yang mengakibatkan gangguan regulasi keratinosit, sel radang, dan pembuluh darah sehingga lesi tampak menebal dengan skuama tebal berlapis. ${ }^{1,2}$ Sel T diketahui berperan penting dalam patogenesis lesi kulit psoriasis. Aktivasi sel $\mathrm{T}$ dalam pembuluh limfe terjadi setelah antigen presenting cell (APC) mempresentasikan antigen tersangka melalui major histocompatibility complex (MHC) dan diikat oleh sel $\mathrm{T}$ naif. ${ }^{1,2}$ Pengikatan sel $\mathrm{T}$ terhadap antigen selain melalui reseptor sel $\mathrm{T}$, dilakukan pula oleh ligan dan reseptor tambahan yang dikenal sebagai kostimulasi. Setelah teraktivasi, sel $\mathrm{T}$ berproliferasi menjadi sel $\mathrm{T}$ efektor dan sel T memori yang kemudian masuk ke dalam sirkulasi sistemik dan bermigrasi ke kulit. ${ }^{1,2}$ Sel CD4+ merupakan subset sel $\mathrm{T}$ di dermis yang terpolarisasi oleh $T$ helper 1 (Th1), sementara CD8+ di epidermis terpolarisasi oleh $\mathrm{T}$ sitotoksik (Tc1) sehingga pada lesi psoriasis ditemukan banyak sitokin. Subset lain dari CD4+ adalah IL-17 (Th17) dan IL-22 (Th22) yang berperan mempertahankan inflamasi kronik pada psoriasis. ${ }^{1,2}$ Memahami jalur imunopatogenik psoriasis pada tahap selular dan molekular penting untuk menentukan pemilihan terapi psoriasis, khususnya penggunaan bahan biologik yang bekerja secara spesifik pada limfosit $\mathrm{T}$ dan sitokin TNFa, IL-12, IL-23, dan IL-17A. ${ }^{5}$

Psoriasis menimbulkan dampak psikososial yang besar dan mengurangi kualitas hidup penderitanya. Kulit dengan lesi psoriasis akan tampak kering dan mengelupas akibat percepatan proliferasi keratinosit, serta dapat meluas ke seluruh tubuh hingga membentuk eritroderma psoriatika. Psoriasis saat ini diketahui memiliki kaitan erat dengan komorbiditas seperti psoriasis artritis, obesitas, penyakit kardiovaskular, non-alcoholic liver disease, sindrom metabolik, dan inflammatory bowel disease yang dapat memperburuk kualitas hidup dan menurunkan angka harapan hidup pasien.
Psoriasis bermanifestasi di kulit sebagai bercak merah bersisik pada bagian tubuh terutama daerah ekstensor dan kulit kepala, yang dapat disertai rasa gatal. Berdasarkan tipenya, psoriasis dibagi menjadi psoriasis plak (psoriasis vulgaris), psoriasis gutata, psoriasis pustulosa generalisata/lokalisata, psoriasis inversa, dan eritroderma psoriatika. Psoriasis plak merupakan bentuk psoriasis terbanyak dengan lesi berupa plak eritematosa berbatas tegas dengan skuama keperakan berlapis. Daerah predileksi psoriasis plak adalah siku, lutut, kepala, celah intergluteal, palmar dan plantar. Psoriasis gutata merupakan tipe psoriasis dengan bentuk lesi berupa tetesan air, plak merah muda dengan skuama pada badan dan ekstremitas, dengan awitan mendadak umumnya setelah infeksi streptokokus pada saluran napas atas. Psoriasis pustulosa generalisata, biasa disebut von Zumbusch, merupakan psoriasis dengan lesi berupa pustul steril pada sebagian besar tubuh dan ekstremitas. Pada tipe ini, fungsi perlindungan kulit hilang sehingga terjadi hilangnya cairan dan nutrisi tubuh, serta pasien rentan terhadap infeksi. Pada psoriasis inversa, lesi terdapat di daerah lipatan, glans penis, atau aksila. Eritroderma psoriatika merupakan perluasan psoriasis vulgaris dengan manifestasi eritema yang luas disertai skuama pada hampir $100 \%$ luas permukaan tubuh. Pada eritroderma psoriatika, fungsi kulit juga terganggu sehingga pasien rentan terhadap infeksi dan temperatur tubuh tidak terkontrol, sehingga dapat membahayakan nyawa., ${ }^{2,61}$

Tujuan terapi psoriasis adalah tidak ada lesi, sehingga pemberian terapi dapat dimodifikasi secara perorangan. Selain identifikasi tipe, derajat keparahan psoriasis perlu ditentukan guna memilih tata laksana yang sesuai. Derajat keparahan psoriasis ditentukan dengan skor body surface area (BSA) atau psoriasis area and severity index (PASI). Berdasarkan Panduan Praktik Klinis (PPK) RSCM dan Perhimpunan Dokter Spesialis Kulit dan Kelamin Indonesia (PERDOSKI), klasifikasi psoriasis berdasarkan skor BSA/PASI adalah sebagai berikut; < 3\% psoriasis ringan, 3-10\% psoriasis sedang, $>10 \%$ psoriasis berat. $^{6}$ Klasifikasi ini sedikit berbeda dengan klasifikasi Fitzpatrick ${ }^{2}$ yaitu; $<10 \%$ psoriasis ringan, $10-20 \%$ psoriasis sedang, $>30 \%$ psoriasis berat. Pemilihan terapi lini pertama untuk psoriasis ringan adalah pengobatan topikal misalnya emolien, kortikosteroid, keratolitik, retinoid, analog vitamin D, atau tar. Bila tidak memberikan respons yang baik, dapat dilakukan fototerapi. Untuk psoriasis sedang, terapi lini pertama yang disarankan adalah fototerapi dengan ultraviolet $\mathrm{B}$ (UVB) broadband (BB) atau Ultraviolet B (UVB) narrowband (NB). Sebagai lini kedua, dapat diberikan kombinasi psoralen dan ultraviolet A (PUVA). Apabila tidak memberikan respons, dapat diberikan terapi sistemik. Pada psoriasis derajat berat, diberikan terapi sistemik, yaitu metotreksat, siklosporin, asitretin, serta dapat dipikirkan pemberian obat biologik. Pada kondisi 
khusus dapat diberikan terapi sistemik pada kasus psoriasis ringan, yaitu pada keadaan keterlibatan area luas pada kulit yang tidak responsif pada terapi topikal, keterlibatan daerah yang tampak seperti tangan, dan wajah, serta keterlibatan area yang resisten terhadap pengobatan topikal. ${ }^{6}$

Keberhasilan terapi psoriasis diukur berdasarkan beberapa indikator, yaitu keparahan kelainan kulit berdasarkan BSA/PASI dan dampak penyakit pada kualitas hidup pasien yang dihitung dengan Dermatology Life Quality Index (DLQI). ${ }^{2,6}$ Terapi psoriasis dikatakan berhasil bila PASI 75 tercapai, yaitu penurunan $75 \%$ dari skor PASI. Terapi psoriasis dikatakan gagal apabila PASI 50 tidak tercapai, yaitu tidak tercapainya penurunan $50 \%$ dari skor PASI. ${ }^{5,6}$ Berdasarkan skor DLQI, terapi psoriasis dikatakan berhasil bila DLQI $<5$ dan dikatakan gagal bila DLQI > 5.6,8

Rumah Sakit Umum Pusat Nasional dr. Cipto Mangunkusumo merupakan rumah sakit layanan tersier yang menjadi rujukan nasional di Indonesia sehingga kasus psoriasis yang terdapat di RSCM sangat bervariasi. Pemilihan tata laksana psoriasis di RSCM didasari Panduan Praktik Klinis (PPK) dRSCM dan PERDOSKI. Ketidaksesuaian terapi psoriasis memengaruhi masa remisi dan keberhasilan pengobatan, oleh karena itu pemilihan terapi yang sesuai sangat diperlukan. Penelitian ini bertujuan menilai kesesuaian tata laksana psoriasis berdasarkan derajat keparahan berdasarkan PPK RSCM dan PERDOSKI.

\section{METODE PENELITIAN}

Penelitan ini merupakan studi retrospektif dengan subjek seluruh pasien baru psoriasis di Poliklinik Divisi Alergi Imunologi, Departemen Ilmu Kesehatan Kulit dan Kelamin RSCM periode Oktober 2017 - Oktober 2018. Pemilihan terapi psoriasis ditentukan berdasarkan derajat keparahan psoriasis yang didasari dari skor BSA/PASI. Data pasien didapatkan dari electronic health record (EHR) serta rekam medis fisik. Informasi berupa nomor rekam medis, nama, usia, diagnosis, tipe psoriasis, skor BSA/PASI, terdapat penyulit berupa psoriasis artritis, serta terapi yang diberikan dicatat secara lengkap dan dianalisis menggunakan statistical package for the social sciences (SPSS) 20. Pasien dengan rekam medis yang tidak lengkap dikeluarkan dari penelitian ini.

\section{HASIL DAN DISKUSI}

Terapi psoriasis ditentukan dari keparahan yang didasari dengan skor BSA dan PASI. Sebanyak 32 di antara 35 pasien $(91,4 \%)$, skor BSA dan/atau PASI terdokumentasi pada rekam medis. Subjek dengan rekam medis yang tidak tercantum skor BSA/PASI dengan lengkap dieksklusi dari penelitian ini. Berikut adalah persebaran subjek berdasarkan tipe psoriasis dan ada atau tidaknya psoriasis artritis.

\section{Tipe psoriasis}

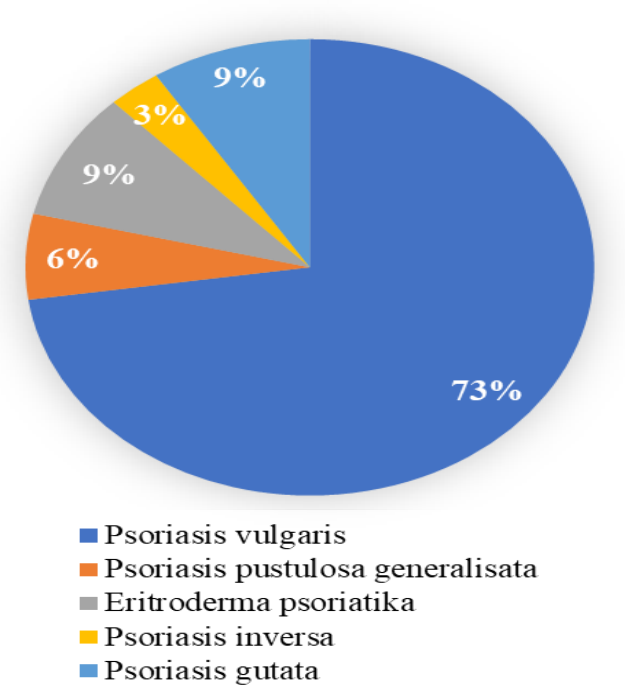

Gambar 1. Klasifikasi psoriasis.

\section{Psoriasis artritis}

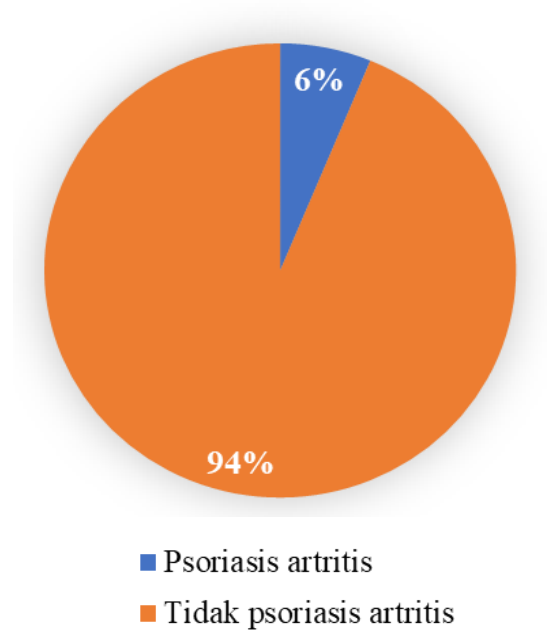

Gambar 2. Psoriasis artritis pada subjek.

Sejumlah 23 dari 32 pasien psoriasis (73\%) yang berobat di Poliklinik Divisi Alergi Imunologi, Departemen Ilmu Kesehatan Kulit dan Kelamin (IKKK) RSCM periode Oktober 2017 sampai September 2018, adalah psoriasis vulgaris. Secara klinis psoriasis vulgaris bermanifestasi sebagai plak berwarna kemerahan berbatas tegas dengan letak predileksi pada lutut, siku, kepala dan sakrum. Psoriasis vulgaris merupakan tipe tersering yang 
terdapat pada hampir $90 \%$ pasien psoriasis. $^{2}$ Tipe psoriasis terbanyak kedua di RSCM adalah psoriasis gutata dan eritroderma psoriatika dengan masing-masing tipe berjumlah 3 pasien (9\%). Psoriasis gutata lebih sering terjadi pada usia anak dan dewasa muda, dengan ciri khas lesi seperti tetesan air yang umumnya timbul mendadak setelah infeksi streptokokus. Bila terjadi regresi, infeksi lesi akan menghilang secara spontan dan dapat bertahan sekitar 3-4 bulan. Lesi psoriasis gutata dapat membesar dan membentuk psoriasis vulgaris. Pada eritroderma psoriatika, lesi mencapai hampir seluruh luas permukaan tubuh. Eritroderma psoriatika dapat merupakan perluasan psoriasis vulgaris, namun dapat pula terjadi secara independen. Pada kasus ini, renjatan kardiovaskular dan sepsis dapat terjadi, sehingga diperlukan pemantauan secara khusus dengan rawat inap untuk mencegah mortalitas. ${ }^{9}$

Selanjutnya, terdapat 2 pasien $(6 \%)$ dengan tipe psoriasis pustulosa generalisata yang biasanya jarang terjadi. $^{10}$ Psoriasis pustulosa generalisata umumnya ditemukan pada usia dewasa muda, lesi psoriasis jenis ini berupa pustul steril yang dapat merupakan akibat komplikasi psoriasis vulgaris, atau akibat penggunaan steroid yang dihentikan secara mendadak. Pada psoriasis jenis ini, dapat terjadi gejala klinis berupa demam, malaise, dan polyarthralgia. Pemeriksaan laboratorium dapat menunjukkan leukositosis, peningkatan sedimentasi eritrosit, ataupun keseimbangan nitrogen yang negatif pada pemeriksaan darah. Psoriasis tipe ini dapat berlanjut menjadi eritroderma psoriatika yang dapat membahayakan jiwa sehingga perlu dilakukan rawat inap untuk pemantauan rutin dan mencegah terjadinya komplikasi. Setelah kondisi terkontrol pasien diperbolehkan rawat jalan. Tipe psoriasis inversa terjadi pada satu pasien (3\%). Pada psoriasis jenis ini, lesi terjadi pada daerah lipatan, dengan ciri khas lesi berupa plak dengan fisura. Psoriasis inversa sering ditemukan pada pasien obesitas dan biasanya resisten dengan pengobatan standar. ${ }^{2,10}$

Ditemukan dua pasien $(6 \%)$ dengan psoriasis artritis dari 32 pasien baru psoriasis. Umumnya psoriasis arthritis terjadi sekitar 5,4\%-7\% dari kasus psoriasis. Psoriasis artritis umumnya terjadi pada dekade ketiga, dengan $10 \%$ kasus psoriasis artritis terjadi sebelum lesi kulit muncul. Terdapat 5 subtipe psoriasis artritis, yaitu tipe klasik sering terjadi pada sendi distal interfalang, serta artritis oligoartikular asimetris yang sering terjadi pada sendi lutut, metakapofalang dan sendi metatarsofalang. Setelah itu terdapat jenis symmetric poliarticular yang menyerupai reumatik artritis. Jenis ke empat adalah tipe artritis mutilans yang sering menyebabkan osteolisis sendi falang dan metakarpal. Variasi terakhir adalah jenis spondilitik, yang merupakan jenis psoriasis artritis yang paling jarang terjadi $(2-4 \%){ }^{2,9}$

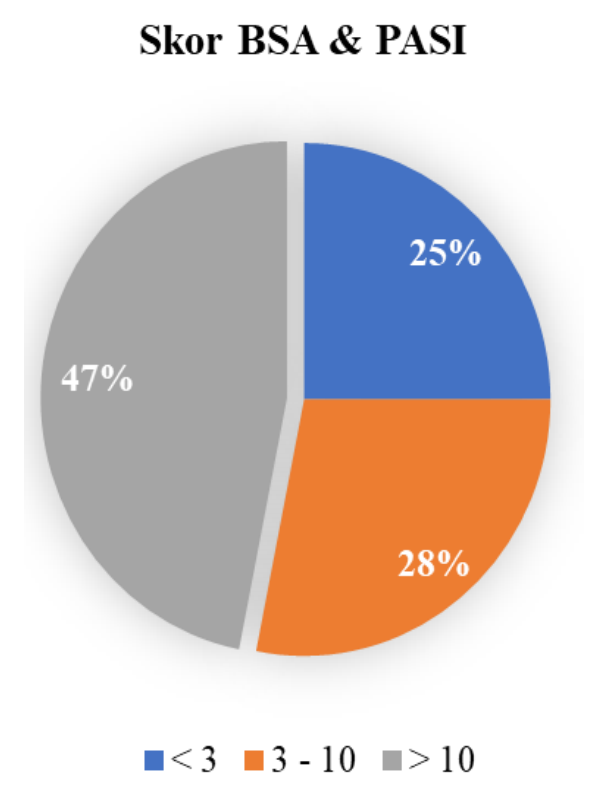

Gambar 3. Skor BSA/PASI

Tata laksana

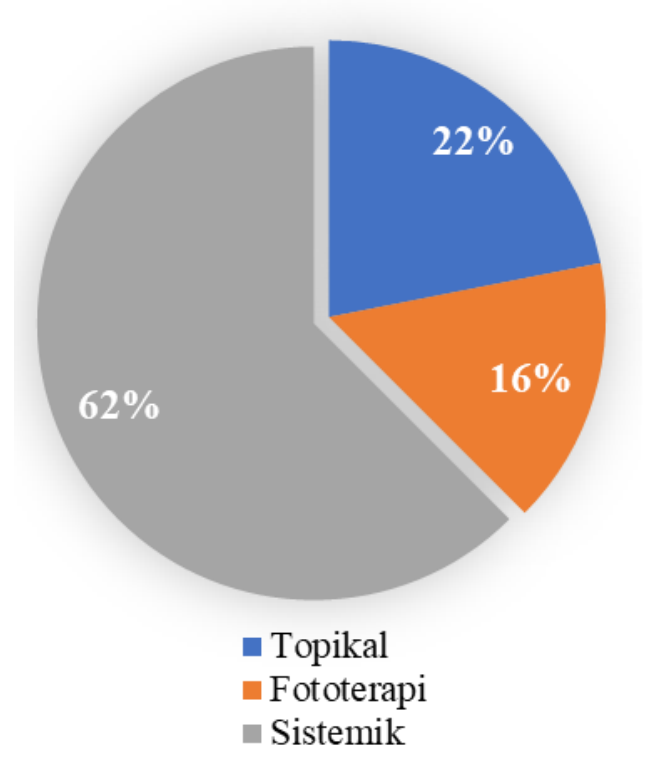

Gambar 4. Terapi Psoriasis

Dalam penelitian ini, keparahan psoriasis berdasarkan BSA/PASI mengikuti klasifikasi PPK PERDOSKI. ${ }^{6}$ Klasifikasi ini sedikit berbeda dari klasifikasi Fitzpatrick yang membagi ringan $<10$, sedang $10-30$, dan berat $>30{ }^{2}$ Perbedaan ini dikarenakandikaitkan dengan pertimbangan gangguan kualitas hidup yang terjadi pada pasien psoriasis cukup berat, serta meningkatnya risiko sindrom metabolik khususnya penyakit jantung koroner yang dapat 
mengancam jiwa pada pasien psoriasis yang tidak terkontrol lesinya, sehingga di Indonesia menggunakan panduan tata laksana yang lebih agresif. ${ }^{6}$

Sebagian besar pasien yang datang ke poliklinik termasuk dalam psoriasis berat dengan skor BSA/PASI $>10$ yang berjumlah 15 orang $(47 \%)$. Jumlah pasien dengan derajat keparahan berat, lebih banyak terjadi karena RSCM merupakan rumah sakit layanan tersier rujukan nasional yang menerima pasien rujukan dari berbagai layanan primer dan sekunder di Indonesia. Kasus psoriasis ringan dan sedang yang belum membutuhkan terapi sistemik, khususnya metotreksat, lebih banyak ditangani di layanan primer dan sekunder. Psoriasis derajat sedang merupakan posisi terbanyak kedua setelah psoriasis berat, dengan skor BSA/PASI 3-10, dan jumlah pasien 9 orang $(28 \%)$, diikuti dengan psoriasis ringan dengan skor BSA/PASI <3\% yang berjumlah 8 orang $(25 \%)$.

Sebagian besar pasien di Poliklinik Alergi Imunologi IKKK RSCM, yaitu sebanyak 20 orang pasien (62\%) mendapatkan terapi sistemik. Terapi sistemik yang diberikan umumnya adalah metotreksat yang merupakan terapi lini pertama pengobatan psoriasis berat, dan psoriasis sedang yang tidak memberikan respons baik pada fototerapi. Sejumlah 7 subjek mendapatkan terapi topikal saja (22\%). Terapi topikal yang diberikan umumnya adalah tar $3-5 \%$ dalam vaselin album untuk lesi di tubuh. Tar 3\% dalam oleum cocos untuk lesi di kepala, dan kortikosteroid topikal potensi 1 . Sebanyak 5 subjek mendapatkan fototerapi (16\%) yang umumnya adalah ultraviolet B broadband (BB-UVB) atau ultraviolet B narrowband (NB-UVB).

Tabel 1. Persentase kesesuaian terapi psoriasis berdasarkan panduan praktik klinis (PPK)

\begin{tabular}{cccc}
\hline $\begin{array}{c}\text { Keparahan } \\
\text { (Skor BSA / PASI) }\end{array}$ & $\begin{array}{c}\text { Jumlah } \\
\text { Pasien }\end{array}$ & $\begin{array}{c}\text { Tata laksana } \\
\text { sesuai PPK }\end{array}$ & $\begin{array}{c}\text { Persentase } \\
\text { kesesuaian }(\%)\end{array}$ \\
\hline Ringan $(<3)$ & 8 & 7 & 87,5 \\
Sedang $(3-10)$ & 9 & 9 & 100,0 \\
Berat $(>10)$ & 15 & 14 & 93,3 \\
\hline Total & 32 & 30 & 93,8 \\
\hline
\end{tabular}

Sebanyak 30 di antara 32 pasien $(93,8 \%)$, mendapatkan pilihan terapi sesuai dengan tipe psoriasis atau skor BSA dan/atau PASI. Kesesuaian terapi tidak mencapai $100 \%$ karena kontraindikasi pemberian terapi standar, penolakan pasien, dan ketidaktersediaan obat misalnya metotreksat. Sebanyak $93,8 \%$ pasien psoriasis di RSCM telah ditata laksana sesuai dengan PPK RSCM dan PERDOSKI.

Pasien psoriasis berisiko mengalami gangguan psikososial yang besar akibat stigma masyarakat serta penerimaan diri yang rendah terhadap penyakitnya sehingga pemberian terapi yang sesuai sangat diperlukan untuk mencapai keberhasilan terapi, yaitu tercapainya PASI 75. ${ }^{13}$ Psoriasis termasuk dalam penyakit kronis misalnya diabetes, hipertensi, dan penyakit jantung koroner yang membutuhkan tata laksana komprehensif jangka panjang untuk mengontrol penyakitnya. Pemberian terapi jangka panjang membutuhkan kontrol rutin untuk penyesuaian dosis serta jenis terapi secara berkala sesuai dengan variasi kondisi pasien dari waktu ke waktu. ${ }^{13}$

Dalam penelitian ini seorang pasien dengan psoriasis berat tidak diberikan terapi sistemik karena merupakan kontraindikasi terhadap metotreksat, yaitu fungsi hepar yang terganggu akibat penyakit hepatitis. Kontraindikasi tersebut perlu menjadi perhatian khususnya untuk pengobatan jangka panjang seperti pada penyakit psoriasis. Untuk mengantisipasi hal tersebut, di RSCM dilakukan penapisan rutin untuk mengidentifikasi adanya kontraindikasi pada pasien dalam persiapan pemberian metotreksat. Keberhasilan terapi psoriasis berhubungan erat dengan kepatuhan pasien dalam menjalankan terapi yang diberikan sehingga dalam pemilihan terapi perlu dipertimbangkan faktor kenyamanan pasien, khususnya dalam pemberian terapi yang menimbulkan banyak efek samping. ${ }^{2,6}$

Dalam penelitian ini terdapat pasien yang menolak dilakukan fototerapi yang merupakan terapi standar yang sesuai dengan keparahan psoriasis pasien berdasarkan skor BSA/PASI. Pasien tersebut menolak fototerapi karena sulit mengakses fasilitas fototerapi yang jauh dari lokasi tempat tinggal pasien, sehingga dipilih modalitas lain untuk terapi pasien tersebut. Kemudahan pasien untuk mengakses fasilitas fototerapi yang membutuhkan kunjungan rutin perlu dipertimbangkan dalam pemilihan terapi. Sehingga apabila memang tidak mungkin dilakukan, dapat dipilih terapi lain, misalnya terapi sistemik sesuai indikasi agar PASI 75 dapat tercapai.

Selain faktor kepatuhan pasien, pemilihan tata laksana psoriasis yang tepat juga penting untuk aspek ekonomi. Tata laksana psoriasis membutuhkan biaya yang besar karena kebutuhan terapi jangka panjang secara terus menerus, khususnya apabila membutuhkan terapi sistemik. ${ }^{14}$ Di Amerika Serikat, National Psoriasis Foundation melaporkan antara tahun 2003 hingga 2011, keterlambatan memulai pengobatan sistemik, mengganti pengobatan, penghentian pengobatan lalu memulai kembali, serta pengurangan dosis yang sebelumnya telah ditingkatkan adalah masalah yang umum terjadi dan menyebabkan pengeluaran biaya melebihi seharusnya. ${ }^{15}$ Dengan demikian, penilaian kesesuaian terapi psoriasis merupakan upaya penting yang perlu dilakukan secara berkala agar dapat tercapai pemberian terapi yang tepat dan optimal untuk pasien psoriasis, dengan tetap mempertimbangkan kebutuhan pasien secara individual. 


\section{SIMPULAN}

Psoriasis merupakan penyakit kronis yang membutuhkan terapi jangka panjang karena dapat memengaruhi mortalitas dan morbiditas. Kesesuaian terapi psoriasis menjadi penting untuk mencapai tujuan dan menjaga kualitas terapi. Sebanyak $93,8 \%$ pasien psoriasis pada penelitian ini sudah diberikan terapi sesuai dengan panduan praktik klinis RSCM dan PERDOSKI.

\section{DAFTAR PUSTAKA}

1. Jacoeb TNA. Psoriasis. Dalam: Menaldi SL, Bramono K, Indriatmi W, penyunting. Ilmu Penyakit Kulit dan Kelamin. Edisi ke-7. Jakarta: Badan Penerbit FKUI; 2017.h.213-22.

2. Gudjonsson JE., Elder JT. Psoriasis. Dalam: Wolff K, Goldsmith LA, Katz SI, penyunting. Fitzpatrick's Dermatology in General Medicine. Edisi ke-8. Mc Grew Hill: New York; 2012.h.197-230

3. Smith HC, Barker JNWN. Psoriasis and its management. Clinical Review. Br Med J. 2006;333:380-4.

4. Vide J, Magina S, Moderate to severe psoriasis treatment challenges through the era of biological drugs. An Bras Dermatol. 2017;92:668-74

5. Gisondi P, Giglio MD, Girolomoni G. Treatment approaches to moderate to Severe Psoriasis. Int J Mol Sci. 2017;18:2427.

6. Widaty S, Soebono H, Nilasari H, dkk. Panduan Praktik Klinis bagi Dokter Spesialis Kulit dan Kelamin di Indonesia.
Jakarta: Perhimpunan Dokter Spesialis Kulit dan Kelamin Indonesia; 2017. h.230-41.

7. Panduan Praktik Klinis Psoriasis, Rumah Sakit Umum Pusat dr. Cipto Mangunkusumo, 2017.

8. Kelompok Studi Psoriasis Indonesia Perhimpunan Dokter Spesialis Kulit dan Kelamin Indonesia. Pedoman tata laksana psoriasis dan informed consent; 2014.

9. Sarac G, Koca TT, Baglan T. A brief summary of clinical types of psoriasis. North Clin Istanbul. 2016;3:79-82.

10. Reich $\mathrm{K}$. The concept of psoriasis as a systemic inflammation: implications for disease management. JEADV. 2012;26:3-11.

11. Daudén E, Castañeda S, Suárez C, García-Campayo J, Blasco AJ, Aguilar MD, dkk. On behalf of the Working Group on Comorbidity in Psoriasis. Clinical practice guideline for an integrated approach to comorbidity in patients with psoriasis. JEADV. 2013;27:1387-404.

12. Ni C, Chiu MW. Psoriasis and comorbidities: links and risks. Clin Cosmet Investig Dermatol. 2014;7:119-32.

13. Zill JM, Dirmaier J, Augustin M, Dwinger S, Christalle E, Härter M, Mrowietz U. Psychosocial distress of patients with psoriasis: Protocol for an assessment of care needs and the development of a supportive intervention. JMIR Res Protoc. 2018:7;7(2)22-8.

14. Fleetcroft R, Parekh-Bhurke S, Howe A, Cookson R, Swift $\mathrm{L}$, Steel N. The UK pay-for-performance programme in primary care: estimation of population mortality reduction. Br J Gen Pract. 2010;60:345-52 